\title{
Problemet Pakistan
}

\section{Michael Jarlner}

Kan atommagten Pakistan falde i hænderne på yderliggående muslimer? Måske ikke lige med det samme - men landet trues af fragmentering og 'talebanisering' i grænseområdet til Afghanistan. Og opløsningen næres af en præsident, der har allieret sig med religiøse partier for at bevare sin egen magt

Nej til religiøs ekstremisme! Pakistan er for alle pakistanere! Ned med mullah-militær alliancen!

Der blev ikke sparet på de store ord, da tusindvis af pakistanere i april drog i demonstration i Pakistans hovedstad, Islamabad. I ugerne og månederne forinden havde hovedstaden nemlig været vidne til et dramatisk - og i skrivende stund uafsluttet - opgør mellem militante muslimer og nogle pakistanske myndigheder, der havde svært ved at finde deres ben at stå på. Begivenhederne rystede de kvinde- og borgerretsaktivister, der denne aprildag havde samlet sig til protest i Islamabad.

"Hvor vover mullaherne at true med at smide syre i ansigtet på kvinder, der ikke tildækker deres ansigt?
Hvordan kan regeringen tillade nogen at oprette en paralleldomstol? Hvorfor står vores magthavere hjælpeløse over for disse mennesker, der bortfører en kvinde og kalder hende prostitueret?", sagde en af aktivisterne, Dr. Farazana Bari, til den pakistanske avis Dawn.

Arnestedet for dramaet var moskekomplekset Lal Masjid, også kaldet Den Røde Moské.

Det begyndte for alvor i januar, da de pakistanske myndigheder rev nogle ulovligt opførte moskeer ned på Lal Masjid-kompleksets område. Moskeens ledelse og de 10.000 studenter rasede. En gruppe tilhyllede kvinder indtog ligefrem et børnebibliotek, som de nægtede at forlade, før den pakistanske regering havde genopført de nedrevne byg- 
ninger. De krævede respekt for islam.

Og kravet blev hurtigt fulgt op af andre af moskeens studerende, der gik til angreb på handlende og markeder, der solgte film og musik, og afbrændte deres musik-cd'er og andre udtryk for 'vestlig dekadence' ude på gaden.

Men ikke nok med det. I marts var det så en gruppe burkaklædte kvinder, der med lange bambuspinde brød ind i et påstået bordel, hvorfra de bortførte både ejeren, hendes datter, svigerdatter og en seks måneder gammel baby og holdt dem som gidsler, indtil regeringen fik dem forhandlet fri.

De studerende krævede respekt for islamiske leveregler, og kravet blev understreget, da moskeen dannede sin egen sharia-domstol, der bl.a. krævede den pakistanske turistministers afgang, fordi hun havde omfavnet sin franske instruktør efter et vellykket faldskærmsudspring.

Og i maj tog nogle af moskeens studerende så en gruppe politifolk til fange i protest mod anholdelsen af nogle medstuderende, som pakistansk politi mistænker for medvirken til terrorisme.

Også den episode landede blødt, efter at moskeen havde truet med at udløse en bølge af selvmordangreb, hvis nogle af de 10.000 soldater, som præsident Musharraf havde indkaldt til at omringe moskekomplekset, gik til angreb. De blev trukket tilbage, en løsning forhandlet på plads, poli- tifolkene løsladt - og ingen blev arresteret.

\section{Helt ind $\mathrm{i}$ hovedstaden}

To ting er slående ved denne kæde af begivenheder.

Den ene er de pakistanske myndigheders frygt for en konfrontation med de militante muslimer, som på deres side hele tiden forsøger at rykke grænsen for deres virke en lille smule længere ud, hver gang statsmagten tøver.

Den anden er, at dramaet udspiller sig inde i selve atommagtens hovedstad og dermed dokumenterer, at den såkaldte 'talebanisering' - religiøse radikalisering - af landet ikke blot er et afghansk-pakistansk grænsefænomen, men altså rækker helt ind i magtcentret. Helt ind i hovedstaden.

Og såmænd ikke bare der, påpeger tænketanken International Crisis Group, der i en rapport fra marts pegede på, at den religiøse radikalisering i allerhøjeste grad også udgår fra nogle af de mange hundrede religiøse skoler - madrasaer - i Pakistans største by og finansielle kraftcenter, millionbyen Karachi.

Herfra er mange sendt af sted som 'hellige krigere' til brændpunkter som Afghanistan og Kashmir, lige som det er sket fra nogle af $\mathrm{Pa}$ kistans tusindvis af andre madrasaer.

Men Karachi har også selv en blodig historie med sekteriske opgør og mord, der i 2006 omfattede selv- 
mordsangreb på tre højt profilerede aktører: I det ene tilfælde blev en amerikansk diplomat myrdet, i et andet døde lederen af en fremtrædende shiamuslimsk gruppe, og i et tredje var det hele ledelsen af en militant sunnigruppe, der blev dræbt som følge af en sunnimuslimsk rivalisering.

"Ikke alle madrasaer i byen er aktive centre for jihadmilitarisme, men selv dem uden direkte forbindelse til vold fremmer en ideologi, der yder religiøs retfærdiggørelse for sådanne angreb”, anfører International Crisis Group.

Den religiøse ekstremisme er vundet frem i et land, hvor skiftende magthavere har udnyttet den til at fremme egne dagsordener.

Mest udtalt var det under den tidligere præsident Zia ul-Haq, der fra 1977 til 1988 stod i spidsen for en omfattende sunnimuslimsk islamiseringsproces af samfundet, hvor han for første gang i landets historie inddrog islamister i sin regering, oprettede shariadomstole, lod staten opkræve religiøse skatter (zakat), fjernede 'uislamiske' bøger fra skoler og universiteter og indførte islamisk undervisning på Militærakademiet. Alle officerer skulle læse en lærebog om Koranens opfattelse af krigsbegrebet, for som Zia ul-Haq skrev i forordet til bogen:

"Den professionelle soldat i en muslimsk hær, der forfølger målene for en muslimsk stat, kan ikke blive 'professionel', hvis han i alle sine gerninger ikke tager farve af Allah”.

\section{Talebans fødsel}

Islamiseringen fandt sted i en periode, hvor der også af andre grunde var grobund for den: Sovjetunionen invaderede Afghanistan, hvilket gav næring til de såkaldte mujahediner, hellige krigere, der fik massiv støtte fra både USA og Pakistan - og som siden udviklede sig til Afghanistans ekstremistiske Talebanbevægelse.

Det afghansk-pakistanske grænseland var af stor strategisk betydning for disse hellige krigere, hvorfor der foregik en tydelig symbiose hen over grænsen.

Læg dertil, at ayatollah Khomeini i 1979 havde gennemført sin shiamuslimske revolution i nabolandet Iran og med sit mål om at eksportere 'den islamiske revolution' havde skabt voldsom bekymring hos sunnimuslimske ledere i både Pakistan og rundt om i den arabiske verden. De så en interesse i en ideologisk oprustning, og igen var Irans nabo Pakistan en vigtig frontlinje og de religiøse skoler - madrasaerne - et velegnet instrument.

"I denne proces blev Pakistan til en slagsmark for en intern islamisk stedfortræderkrig", hedder det da også direkte i den pakistanske journalist Zahid Hussains nye bog Frontlinje Pakistan:

"Madrasaerne, der blev finansieret af Saudi-Arabien, Kuwait og andre Golfstater, især efter den sovjetiske 
invasion af Afghanistan, blev til et centrum for såvel sunnimilitarisme som for sekteriske organisationer".

Denne periode lagde en afgørende grundsten til samspillet mellem især de radikale islamiske grupper, madrasaerne og den pakistanske efterretningstjeneste ISI, der siden skulle bruge den afghanske Talebanbevægelse til at udvide sin indflydelsessfære. I hvert fald lige indtil 2001, da terroraktionerne mod USA den 11. september fik Bush-administrationen til at kræve, at den nuværende præsident Musharraf valgte side og gik med i kampen mod det talebanstyre, han selv havde været med til at skabe.

\section{Den religiøse dagsorden}

"Musharrafs beslutning om at indgå partnerskab med USA var det samme som at lade Pakistan gå i krig med sig selv", påpeger Zahid Hussain i sin bog: "Og resultatet af det opgør vil ikke blot have betydning for Pakistans egen skæbne, men også for det ideologiske klima i Mellemøsten og for verdens sikkerhed".

Det er ingenlunde nogen let sag. Selv om Pervez Musharraf selv har et mere sekulært tilsnit og bl.a. siges at have det moderne Tyrkiets landsfader, Mustafa Kemal Atatürk, som forbillede, så er han efter valget $\mathrm{i} \mathrm{Pa}-$ kistan i 2002 søgt ind i en alliance med en stribe religiøse partier, der har sat sig på magten i provinserne Balochtistan og Den Nordvestlige
Grænseprovins (NWFP). Formålet med alliancen er at holde forgængerne Benazir Bhuttos Pakistans Peoples Party (PPP) og Nawaz Sharifs Pakistan Muslim League fra magten.

På den måde er han blevet viklet ind $\mathrm{i}$ en religiøs dagsorden, der $\mathrm{i}$ områder som Waziristan og Den Nordvestlige Grænseprovins allerede har ført til en så omfattende 'talebanisering', at militante har tvunget internetcafeer, video- og musikbutikker til at lukke, mens lokale barberer har fået besked på ikke at barbere skægget af folk, og det er blevet forbudt at se tv og spille musik, selv til bryllupper.

Og det er denne religiøse dagsorden, der har fået ham til at opgive de opgør med militante muslimer og madrasaer, som han bebudede ved sin tiltrædelse, og som ikke blot er rene pakistanske fænomener. De omfatter eksempelvis også madrasaer, der er blevet sat i forbindelse med såvel de folk, der stod bag terroraktioner i London i $2005 \mathrm{og}$ sidste års forpurrede planer om angreb mod fly fra London til USA.

"Ved at udnytte regeringens svaghed har de religiøse partier og madrasasammenslutninger imødegået alle forsøg på at regulere madrasasektoren", skriver International Crisis Group i føromtalte rapport:

"Ved at træde tilbage har regeringen yderligere styrket de sekteriske og ekstremistiske kræfter, hvilket har resulteret i et betydeligt bidrag til den vold, der plager Karachi 
og i høj grad resten af landet”.

Zahid Hussain er ikke mildere i sin dom: "Pakistan står muligvis ikke over for en umiddelbar trussel om en fundamentalistisk islamisk magtovertagelse, men der er en klar fare for en fragmentering, hvor radikale muslimer kontrollerer dele af landet”, skriver han og tilføjer kort tid efter:

"Talebaniseringen af Waziristan og den stigende magt hos radikale mullaher i dele af Den Nordvestlige Grænseprovins udgør et foruroligende scenario. Det ville være svært at inddæmme spredningen af denne udvikling til andre dele af landet".

Udviklingen understøttes af en tiltagende fattigdom, der allerede rammer en tredjedel af Pakistans 160 millioner store befolkning, og som i sig selv vil bidrage til en religiøs radikalisering. Det sker alene af den grund, at mange fattige ser de religiøse skoler, madrasaerne, som det bedste skoletilbud, de har råd til med skolernes tilbud om gratis mad, tøj og undervisning.

Fra udlandet lyder rådet til Pervez Musharraf, at han hurtigst muligt bør træde tilbage og genåbne den demokratiske proces i forbindelse med det planlagte valg i efteråret.

Indtil videre har han reageret ved at fyre chefen for den højesteret, som kunne have hindret ham $i$ at forlænge sit eget styre - som general og som præsident.

Der er grund til at være bekymret for atommagten, og ikke bare i forhold til Den Røde Moske. Begivenhederne dér er blot et symptom på den pakistanske syge.

Michael Jarlner er udenrigsredaktør på Politiken 